University of Nebraska - Lincoln

DigitalCommons@University of Nebraska - Lincoln

December 1970

\title{
Economic Sophistication in Nineteenth Century Congressional Tariff Debates
}

Richard C. Edwards

redwards1@unl.edu

Follow this and additional works at: https://digitalcommons.unl.edu/econfacpub

Part of the Economics Commons

Edwards, Richard C., "Economic Sophistication in Nineteenth Century Congressional Tariff Debates" (1970). Economics Department Faculty Publications. 5.

https://digitalcommons.unl.edu/econfacpub/5

This Article is brought to you for free and open access by the Economics Department at DigitalCommons@University of Nebraska - Lincoln. It has been accepted for inclusion in Economics Department Faculty Publications by an authorized administrator of DigitalCommons@University of Nebraska - Lincoln. 


\section{Economic Sopbistication in Nineteenth Century Congressional Tariff Debates}

We are lost at once amidst the jargon of the schools of political economy.

Representative Mallory

February 28, 1824

(Annals of the Congress)

$\bigcirc N$ $\mathrm{NE}$ of the most controversial economic issues confronting the American public during the nineteenth century was that of protection. The plea for a protective tariff had been raised as soon as the First Congress met in 1789. The issue was sharply debated off and on throughout the nineteenth century but never finally resolved. There is now a large literature relating the outcome of this issue to the economic and political interests of various involved groups.

Little effort has been made, however, to assess the impact of the tariff on economic growth, employment, and the dispersion of new technology. Nor has a close examination been made of the thought of Congressmen who participated in the tariff debates. To what extent can one characterize those debates as informed by a knowledge of economic theory? What body of theory was available for them to draw upon? In short, what was the intellecutal basis as perceived and understood by the Congressmen themselves, of the tariff judgments which they made?

This paper attempts to answer those questions by scrutinizing the tariff debates of 1824 and 1894 as case studies. Is there evidence in the debates to indicate that Congressmen were perceptive to the operation of a national economy? How economically knowledgeable were they?

\section{SOME PRELIMINARIES-A METHODOLOGY}

By "economic knowledge" I mean systemic, theoretical knowledge of the economy. As practical men, Congressmen knew a great

The author wishes to thank Professor Alexander Gerschenkron, who first inspired this paper and for whose course an early version was written. Carolyn Pope Edwards and a referee greatly improved the paper's prose. 
deal about those particular segments of the economy in which they were engaged or which affected them. My concern, however, is with the Congressmen's understanding of the economy as a system, their understanding not only of the parts but also of how the parts influence each other. It is only this broader knowledge that is appropriate for national policy formulation.

There are several limitations to this study that must be noticed from the beginning. First, I shall not attempt to appraise the extent to which economic arguments were persuasive to the members or influential in determining votes. I shall ask only what economic knowledge was displayed and not how behavior was affected by it. ${ }^{1}$ Second, I shall make no effort to trace the undoubted effects on the expressions of Congressmen of their constituents' economic interests.

The third limitation is somewhat more serious methodologically. Because for each case study I wish to survey an entire Congress, I rely on the one source we have which records that Congress acting as a unit, namely the transcript of its debates. If an investigator were attempting to discover the economic knowledge of a certain member of those Congresses, it is clear that he would not confine his study to the man's speeches in Congress; in fact, it might be thought that these speeches, being nearly barren of direct economic exposition, would conceal more than they revealed of his expertise. However, because my task concerns two entire Congresses this paper must deal with the Congresses somewhat abstractly - treating them as if they were composed of two homogeneous parts, the tariff supporters and the free-traders. My concern is ascertaining whether or not there existed systems of "political economy" that underlay these two positions, and if so, what they were. Therefore, despite the dangers mentioned above, I shall rely solely on these debates for my data.

Further, I have limited this study to the debates in the House of Representatives, which always debates tariff bills before they go to the Senate. This limitation represents no serious restriction, since the House generated more genuine controversy, and the time constraints placed on speakers kept the debates more germane. The source for the debates is the Congressional Record, ${ }^{2}$ for the 1894

1 If our concern were behavioral, we should have to investigate the considerable power of unsystematized ideas, even quite unsophisticated ones, to accomplish political objectives in a society which historically has been notable for its distrust of systematic thought.

2 Congressional Record: Containing the Proceedings and Debates of the Fifty- 
debates, and its predecessor, the Annals of Congress ${ }^{3}$ for the earlier debates. Although the Annals is not quite a primary source, being a compilation of the Congressional stenographers' notes, it records nearly all of the debates verbatim, and thus there is no serious discrepancy between the Annals and what the primary source might be considered to have been.

Finally, this study must be qualified in two different ways, whose effects hopefully cancel each other out. The first is that the models described below result from an artificial synthesis of many men's ideas, and I cannot claim that any one Congressman had systematized these ideas into a consistent model. What I do claim is that all of these ideas were present in the debates and were used to advantage by the participants. The second qualification is that the "free-trade" and "pro-tariff" models come as much from an intuitive feel for the debates-derived from careful reading of the House proceedings for each debate-as from the quotations presented below. For every statement quoted that concisely states a relevant idea, there were many more that were less concise in statement or less precise in content.

I have dealt at some length with these methodological problems because they appear particularly acute in such a study-necessarily qualitative and somewhat speculative-which involves abstracting economic models from speeches made for entirely different ends. Nevertheless, despite these limitations, the results are of considerable interest.

\section{CASE ONE: THE DEBATE OF 1824}

A tariff primarily designed for protection was first seriously debated in the Congress of 1816. Domestic manufacturers had prospered during the period of non-tariff protection caused by the wartime collapse of international commerce. In 1816, with the return of peace, the United States was flooded with foreign, primarily British, manufactured goods. There was general agreement in the Congress that some type of tariff was needed to ease the adjustment.

The 1816 solution to the tariff question was ambiguous in terms of long-range policy. The Congressional debate focused on short-run

Third Congress, Second Session (Washington: Government Printing Office, 1894), Parts I, II, and Appendix, Part I.

3 The Annals of the Congress of the United States, Eighteenth Congress, First Session (Washington: Gales and Seaton, 1854), Volumes 41 and 42. 


\section{Congressional Tariff Debates}

adjustments, and that portion of the debate which did involve longrun policy was generaly desultory. In the following years there was increased pressure for general tariff protection for domestic industry - pressures that culminated in the election of the 18th Congress in 1822, the first Congress elected under the census of 1820. In the first session, a major revision of the tariff was introduced into the House of Representatives. This tariff, known as the Tariff of 1824, was debated from December of 1823 until April of 1824.

The debates cover roughly a thousand pages in the Annals, although for each side of the principal substantive arguments were articulated by a few major speakers. The final vote passing the bill strikingly demonstrated the regional conflict of interests. Each of the twelve proto-industrial Central States voted overwhelmingly in favor of the bill, and as a group provided a 95 to 10 margin in favor. ${ }^{4}$ Eleven other states, the mercantile Northeast and agricultural South, all voted solidly against the bill, producing an 84 to 6 bulge in opposition. ${ }^{5}$ Only the Maryland delegation was closely split, voting 5 to 4 against the bill. ${ }^{6} \mathrm{~A}$ considerable portion of the debate was devoted to general economic principles; consequently, the passage of the bill may be correctly interpreted as the result of the considered economic judgment of that Congress concerning a policy of longrange protection. It is these debates, then, that I employ for my first case study.

One can begin his search for underlying economic conceptions, or what will loosely be called models, by focusing first on the economic writers mentioned in the debates. My purpose is not to test how much history of thought the Congress knew; rather, by reviewing their intellectual precursors, hopefully we can gain clues as to their own conceptual schemes.

Foremost was, of course, Adam Smith. The Wealth of Nations, published first in 1776, appears to have been common and almost required reading, as judged by the frequency with which Smith's name appears in the debates. His name is explicitly used at least eight different times by different speakers, ${ }^{7}$ and many more refer-

4 Rhode Island, Connecticut, Vermont, New York, New Jersey, Pennsylvania, Deleware, Kentucky, Ohio, Indiana, Illinois, and Missouri.

s Maine, New Hampshire, Massachusetts, Virginia, North Carolina, South Carolina, Georgia, Tennessee, Louisiana, Mississippi, and Alabama.

6 The final vote is reported in Annals, pp. 2429-2430. Congressmen can be identified from Rapine, D., Congressional Directory, for the Second Session of the Eighteenth Congress of the United States, (Washington City, 1824).

7 Annals, pp. 1559, 1678, 2178, 2222, 2233, 2372, 2391, 2403. 
ences are clearly directed to him (e.g., "Buy where you can buy cheapest, is the maxim of the political economist" ${ }^{\prime \prime}$. Smith's arguments for free trade naturally suited those opposed to the tariff, and his enormous influence in ordering their thinking will be noticed later.

Ricardo's Principles of Political Economy and Taxation did not appear until 1817, and although some of his pamphlets were available earlier, his name is not mentioned frequently. Because the Principles is more purely theoretical than Wealth of Nations, it had less appeal for the Congress. The free-trade group recognized that Ricardo's work provided an intellectual underpinning for its position, ${ }^{9}$ but from the references to the work it appears that while respected, its content remained generally obscure to the debate participants.

J. B. Say's Traité had some circulation among members of the Congress, and perhaps it was through Say that most of Smith's arguments became known. Likewise, the "celebrated Malthus"10 was generally recognized as a political economist of considerable stature. There is little assurance that the speakers who appealed to these latter economists had ever read their works, but they were at least aware of the arguments presented by them. In any event, Adam Smith's name appears to have been most prestigious, and his work was clearly the most influential.

The works of these economists have since been accepted as genuine contributions to economic theory. Given the prevailing intellectual disfavor of tariffs, the tariff supporters were generally wont to dismiss political economists as "abstract and theoretical"11 or "foreign speculative writers." ${ }^{\text {"2 }}$ One economist, Sir James Steuart, had received considerable notice from the tariff advocates in the 1816 debates, since his Political Oeconomy provided some support for the tariff position. ${ }^{13}$ By 1824, the theoretical triumph of the freetraders was so complete that not only was Steuart's name not invoked, but the balance-of-trade doctrine was called "idle and ridiculous, ... . exploded by all the enlightened political economists of

8 Ibid., p. 1476.

Ibid., pp. 2144, 2233, 2235, 2372.

10 Ibid., p. 1682.

11 Ibid., p. 2069.

12 Ibid., p. 1474.

13 See S. R. Sen, The Economics of Sir James Steuart (Cambridge, Mass.: Harvard University Press, 1957). 
the day." ${ }^{14}$ However, Steuart's work continued to influence the debates in fact if not in name.

Aside from these more theoretical writers, the Congress of 1824 was familiar with many of the popular and contemporary economic writers. Joseph Lowe $\mathrm{e}^{15}$ was particularly studied because he presented some of the most valuable of the few available statisticsthose on British customs and currency. Both sides in the debate made repeated reference to Lowe's work. Colquhoun ${ }^{16}$ was popular because he presented empirical matter in analytic terms; he attempted ". . . to paraphrase factually, as it were, the more popular doctrines of the times."17 Laborde, Count Nesselrode, Matthew Carey, and Dr. Seybert, contemporary American and European economic observers, and were all quoted and used.

We see, then, that the Congress was generally familiar with both the theoretic writings and the more popular contemporary materials. On the free-trade side, the theorists had gained such sway as to sweep the opposition from the field; by 1824, there were no intellectually respectable writers supporting the tariff position, so tariff advocates were forced to depend upon the "practical statesmen" of the day or upon such authors as Nesselrode and Lowe, who were mostly problem-oriented. We shall later see this split mirrored in the differing degrees of completeness manifested by the conceptual schemes of the two groups.

\section{The Free Trade Position}

Let us now examine closely those conceptions that underlay the free-trade arguments. We can view in detail the previously noted intellectual debt owed to Adam Smith.

The "Real" Model. First, the free-traders had a clear Smithian conception of the nature of national wealth: "The wealth of a nation consists in the abundance of those articles which administer to the necessities, the comforts, and the luxuries of life, according to the existing habits of society."18 This notion of wealth, frequently repeated, is plainly free from any bullionist concept of wealth. But, more importantly, it implies that anything that increases the stock

14 Buchanan quoting Webster, Annals, p. 1891.

15 Ibid., pp. 1923, 1931, 1940, 1974, 1997, 2021, 2071.

16 Ibid., p. 2248.

17 J. A. Schumpeter, History of Economic Analysis (New York: Oxford University Press, 1954), p. 522n.

18 Annals, George McDuffie (S.C.), p. 2402. 
of "those articles" increases the national wealth. ${ }^{19}$ This implication, though seemingly simple, is of considerable importance to the early nineteenth century legislator. In the first place, it induced the freetraders to begin asking relevant questions (e.g., what causes the stock of "those articles" to increase?). But, more important, by focusing on real goods rather than their money values, this concept of wealth removed from the analysis the economic element most confusing to the legislator: the relation of prices and the value of money to production and income. It allowed the Congressmen to deal in real quantities whose measurement was invariable. As a simplification, it was enormously helpful in arranging economic concepts in a relevant order.

In attempting to answer the question of how a nation arrives at an optimal resource allocation, the free-traders were led to consider four aspects of economic behavior, the first three of which are derived almost directly from Smith:

1) The division of labor and subsequent exchange of products were recognized as the fundamental means of increasing the stock of goods available to society. Both tariff advocates and opponents agreed that "[it is to mutual advantage] ... that a man employs a neighboring mechanic to make his boots and shoes, instead of making them himself. . . ."20 Daniel Webster, in clear reference to Smith's example of growing grapes in Scotland, lays out the need for a division of labor:

if the world had but one clime, and but one soil; if all men had the same wants and the same means ... to gratify those wants ... [then there would be no reason for exchange]. But ... we inhabit a various earth. We have reciprocal wants and reciprocal means for gratifying one another's wants. This is the true origin of commerce, $\ldots$ an exchange of equivalents. ${ }^{21}$

Similarly, the principle of exchange-that both parties gain because each receives an article at least as dear to him as that which is given up-was distinctly pointed out by Webster. ${ }^{22}$ In fact, both sides were willing to admit the advantages of a division of labor, between individuals and between sections of the country; it was generally

19 While there is no explicit mention of an income flow, it is evident from the speeches that the concept of increases in stock approximates a modern flow-of-income wealth definition; the stock-flow problem was simply not recognized by the Congress.

20 Annals, Christopher Rankin (Miss.), p. 2019.

21 Ibid., Daniel Webster (Mass.), p. 2046.

22 Ibid., p. 2046. 
agreed that it was most advantageous for the South to grow cotton, the North to produce manufactured goods, and the West to supply the nation's foodstuffs.

It was only the free-trade advocates, however, who were willing to extend the analysis to an international division of labor which could be mutually advantageous: "Commerce between nations has the same essential character as commerce between individuals." ${ }^{23}$ Or again, "What odds does it make whether the communities are separated by Goose Creek or the great Atlantic?"24 Given the basic definition of national wealth mentioned above, we can see that the advantages of division of labor and exchange, both internal and foreign, were not lost upon the free-traders. The foreign-trade benefits of "buy where you can buy cheapest" constituted an important defense of free trade in these debates.

2) Another Smithian tenet accepted wholeheartedly by the tariff opponents was that of the "invisible hand" or self-interest as a socially desirable motivation. In a passage lifted almost directly from the Wealth of Nations, P. P. Barbour proclaimed:

there is an instinct implanted in man . . . which . . . impels him to a perpetual endeavor to better his condition; that this principle, acting alike on all, without concert, and without even looking to the public interest, every man in society is constantly endeavoring to increase his portion of weath, and, consequently, every man is laboring to add to the stock of public wealth. ${ }^{25}$

Samuel Foot recognized the same idea but linked it directly with the question of the tariff: "The greatest degree of national and individual wealth is obtained by permitting labor, skill, and capital to find their own employment and investment unshackled, and encourage [sic] a free and unrestricted trade." ${ }^{26}$ The notion that unrestricted economic participants pursuing their self-interest reach an optimal employment provided a further basis for attacking the tariff bill. Several speakers declared that the tariff would divert resources from their normal occupations, and since the new occupations must be less profitable (otherwise resource owners would have switched to them voluntarily), a less than optimal solution would be produced. ${ }^{27}$

23 Ibid., Daniel Webster (Mass.), p. 2046.

24 Ibid., Robert Garnett (Va.), p. 2093.

25 Ibid., P. P. Barbour (Va.), p. 1923.

26 Ibid., Samuel Foot (Conn.), p. 2297.

27 See for example Ibid., p. $1923 \mathrm{ft}$. 
3) Competition was recognized as the force that regulated trade and guaranteed the assumption that the national good would result from the sum of private self-interest; Christopher Rankin makes this position clear: "Capital, if permitted, will always find its place of profitable employment. ... Competition ... . [enables] you to purchase from those who can produce or manufacture cheapest. . . . You are not ... subjected to the extortion of those from whom you have no alternative but to buy at their own prices." ${ }^{28}$ Competition on the one hand ensured that prices would be forced down to the minimum possible profitable level; on the other hand, competition among alternative employers in the labor market was relied on to ensure full employment: "If any man were to make his complaint to me that he was without employment, I could tell him simply to go to work ... a remedy in the reach of everyone. ${ }^{29}$

4) Production was thought to depend upon a combination of capital and labor ${ }^{30}$ (and presumably land), the exact combination being determined by the skill and industry of the labor component. Given this type of production function, the size of the output depended on whichever factor was the scare factor-and the Congress clearly believed that labor was the scarce factor: "For a century to come, the population of our country cannot reach such a state of redundancy at materially to reduce the [high] rate of wages." ${ }^{11}$ If one wanted to increase production, then, the principal problem would be to allocate labor to those employments where the returns to labor were greatest. Robert Garnett believed that there were increasing returns to labor in agriculture: in contrast to countries lacking an equally favorable ratio of labor to "first-class" land, Garnett argued that for the United States additional unit labor inputs produced more than equal output increases. In manufacturing, on the other hand, he felt that at best constant returns were available. ${ }^{32}$

The definition of national wealth and these four aspects of economic behavior can be thought of as the basic systemic model of the free-traders. Following from the wealth definition, it is entirely in

28 Ibid., Christopher Rankin (Miss.), p. 2005.

29 Ibid., George McDuffie (S.C.), p. 2407.

30 Ibid., p. 2180.

31 Ibid., Timothy Fuller (Mass.), p. 1706. An even more explicit statement comes from the tariff side: "in this thinly populated country, labor is what we want." Ibid., Henry Martindale (N.Y.), p. 1643.

32 Ibid., pp. 1683-84. 
terms of real goods; prices and money are left out, because they do not affect the underlying "real" processes. We see at once that the free-traders have developed the essential elements of what is now known as the classical model: the amount of production is based on the amount of labor input; all markets are cleared, including the labor market, by the force of competition; the productivity of labor is determined by its employment (the division of labor) and skill (the state of technology).

This model was made dynamic by introducing an historical growth pattern. Agriculture is the first stage of production, and when it is sufficiently well-established, it provides capital for the second stage, foreign commerce. As commerce expands and agriculture matures, both provide capital resources for manufacturing, the third and final stage. Interference in this progression, for example by the introduction of a tariff, would divert resources prematurely and would result in an insufficient foundation for the most advanced stage, thus precipitating failure. ${ }^{33}$

As is typical of a classical model, this model is an optimistic one: if left unfettered, the economy would naturally move to an equilibrium that results in full employment and the optimal product output. Christopher Rankin's reply to the problems posed by wartime disruption of markets ("time alone restores the equilibrium"34) characterized the general faith in this view of the economy.

The model is not complete; it does not develop either a theory of distribution or saving, and it leaves implicit how consumer desires get translated into production decisions. But when it is recalled that the debaters were Congressmen rather than economists, this model will be seen to be remarkably appropriate. It deals concisely with the economic questions raised by the tarriff: it defines national wealth, describes how production is organized, and provides a framework for analyzing the effects of policy changes on production and wealth. It is also clear that this type of model is exactly the one in which the gains from free trade are the greatest-and therefore provides the best justification for opposing the tariff.

Prices, Money, and Interest. When we introduce the free-trade Congressmen's notions of money and prices, the simple model developed above begins to lose its innocence; but it remains essentially a real-good model. While there was considerable confusion sur-

83 Ibid., pp. 1935, 2253.

84 Ibid., p. 2020. 
rounding the monetary system and its relation to prices, it was generally held that money and prices merely reflected the underlying real processes. There was no "natural price" concept analogous to that of Smith or Ricardo. Prices were simply set by the supply and demand conditions prevailing in the market. Daniel Webster, for example, ascribed high wartime prices to the augmented demand caused by unusually high government expenditures. ${ }^{35}$

Prices also were seen to depend on the quantity of money in circulation: "Paper issues of our banks carried the same effect [of enhancing prices] still further."36 However, demand was somehow independent of either money prices or the amount of money available, and reflected only the underlying "real" demand for the article. $^{37}$

The interest rate-properly seen as a return to a factor of production-was taken as an index of the amount of money capital available relative to the demand for it. Here it seems there was no distinction made between real resources for investment and financial resources. The current American interest rate was thought to be somewhat higher than the comparable British rate due to the assumed abundance of British capital. ${ }^{38}$

Because of their fundamental belief in the "real" economic processes, the free-trade advocates saw no dangers in international pricing or the balance of payments. Specie would move in the direction of high demand. ${ }^{39}$ In response to movement of specie, international prices would adjust. But since product demand depended only on the demand for the article (and not on money prices), there would be no output or employment effects resulting from the specie movement. ${ }^{40}$ Consequently, the balance of payments problem was "exploded."

Specific Tariff Arguments. The fragments gathered above into a "model" were of course scattered throughout debates dealing specifically with the tariff. But now that we have seen what kind of economic conceptions lay behind the tariff arguments, we are in a position to understand the nature of those arguments themselves.

The free-traders contended that a tariff would diminish the na-

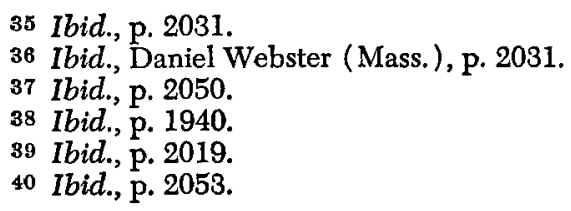


tional wealth by causing future additions to the stock of that wealth to be smaller than would be the case in the absence of the tariff. The argument was developed along two lines:

1) The tariff reduces or precludes the benefits derived from an international division of labor: "With the labor of ten days, I can buy a piece of cloth manufactured in England; whereas, the same sort of cloth, manufactured in the United States would cost me twelve or thirteen days labor, or a value equivalent to that. These are my reasons ... [ [for opposing the tariff]."41

2) The tariff, by encouraging a different allocation of resources, reduces the total domestic output. In the first instance, a tariff encourages too much capital, i.e., that of the inefficient producer, to enter and remain in the industry. ${ }^{42}$ Secondly, it coerces resources into less profitable uses by taxing the consumers to provide a bounty for certain industries. ${ }^{43}$ The cost of this resource diversion is precisely the opportunity cost-the goods that could be produced if the scarce labor had been employed in other occupations. ${ }^{44}$

The tariff opponents refuted both the balance-of-trade argument and the employment problem by refusing to admit that they existed. An unfavorable balance of trade would cause a change in international prices, that is, exchange ratios, which in turn would correct the trade imbalance. But this correction would have no influence on domestic employment. Finally, competition was assumed sufficient to keep the wage rate at the full employment level, so there could be no legitimate argument for the traiff in terms of correcting domestic employment patterns.

\section{The Pro-Tariff Position}

The tariff advocates were not so fortunate as their opponents in inheriting a useful conceptual scheme from the contemporary political economists. Their model remained in a cruder state of development, and their arguments tended to be primarily non-economic in context. The legislators were familiar with the old mercantilist philosophy expounded by Steuart and others, but the mercantilist model had been thoroughly discredited intellectually by Smith's Wealth of Nations. What emerges as the conceptual framework for

\footnotetext{
41 Ibid., Lewis Williams (N.C.), p. 2111.

42 Ibid., p. 1925.

43 Ibid., p. 2086.

44 Ibid., p. 2062.
} 
the pro-tariff position is actually two lines of thought: mercantilist economics and, what is more interesting, a modified KeynesianSmithian system.

We notice first that some of the pro-tariff Congressmen simply refused the arguments of Smith. They accepted a definition of wealth in terms of precious metals: "To be sure, we get an equivalent for our money (in trade), and perhaps more, but we consume it. . . England gets our money, and she does not consume it. This is the secret of her wealth and of our poverty." 45 With such a definition of wealth, the importance of the favorable balance of trade naturally follows: "She [a wise nation] should sell what she can: buy only what she must." ${ }^{\prime \prime}$ For these mercantilists, then, the question of the tariff was essentially one of correcting an imbalance of trade through restricting imports.

The Keynesian-Smithian Framework. The larger portion of the tariff advocates accepted the contributions of the Wealth of Nations, but made some very surprising modifications that changed the policy implications of the model. Smith's definition of wealth in terms of the real goods available to society was considered correct. Also accepted were the observations about economic behavior, specifically the division of labor and self-interest, made by the freetraders. However, it was the free-traders' (and Smith's) assumption of full employment at equilibrium that was disputed by those supporting the tariff and that motivated the insightful modification.

Employment was seen as being directly related to the level of production:

If a farmer has no market for his surplus productions, the supply of his own wants will be the measure of his exertions; and if there be no foreign demand for the surplus produce of the country, the industry [i.e., employment] of the nation will be limited to the supply [i.e., supplying the effective demand] of the nation. The want of a market ... effectually limits the exertions of industry. ${ }^{47}$

But it was also known that aggregate production could exceed the demand ("market") for goods: "[Prosperity or high employment requires that a society possess] a market for the sale and exchange of the surplus of the produce of the labor of its members. This market

45 Ibid., Henry Martindale (N.Y.), p. 1655.

46 Ibid., Henry Martindale (N.Y.), p. 1644.

47 Ibid., Salas Wood (N.Y.), p. 2073. 
should be competent to the absorption of the entire surplus of production." ${ }^{38}$ And if the market demand was not great enough, there would be unemployment:

The products of our agricultural labor begin to be limited to the quantity necessary for mere subsistence, lest the surplus perish on hand for the want of a market at home or abroad. . . . there is a want of employment. How, then, can the greatest number of hands be most productively employed? This is the problem to be solved. ${ }^{49}$

Or, more simply, "Production exceeds consumption, and a portion of the people are without occupation, for want of employment. ${ }^{50}$ Personal consumption clearly depended on income in this model: "The farmer was consuming these importations to the extent of his ability to purchase. ... [ [High war-time income] enabled him to sustain, for a time, habits of expense and indulgence to which he had not been accustomed."'51 Finally, it is clear that the tariff advocates did not view involuntary unemployment as a condition of temporary disequilibrium: "Permanent excess of production over consumption is the only correct criterion [for determining whether foreign trade must be developed]."

It was recognized that aside from the private hardships suffered by those who lost income because they were unemployed, there were national wealth implications to unemployment as well. Unemployed labor was a wasted resource, particularly considering that labor was assumed to be the scarce resource, and therefore: "The interference of Government to procure employment for the surplus population is required to increase the wealth of the nation." ${ }^{\prime 3}$ The Congress of 1824 was thus led to ask what, in terms of economic thought, is a remarkably modern question: "Is full employment provided by the nature and distribution of our occupations?" ph $^{4}$ Though the employment problem is seemingly posed here in structural terms, actually it is more one of aggregate demand: with most of the pop-

48 Ibid., Henry Clay (Ky.), p. 1966. Also: "Production will exceed the consumption of the country and new branches of industry will become necessary." Ibid., Salas Wood (N.Y.), p. 2072.

49 Ibid., James Strong (N.Y.), p. 2127.

5o Ibid., Salas Wood (N.Y.), p. 2073.

51 Ibid., Henry Martindale (N.Y.), p. 1634. See also p. 1965 for similar statements by Henry Clay.

52 Ibid., Salas Wood (N.Y.), p. 2072.

53 Ibid., Salas Wood (N.Y.), p. 2074.

54 Ibid., Henry Martindale (N.Y.), p. 1633. 
ulation engaged in agriculture and supplied with manufactured products from Britain, there simply was insufficient "market" or "consumption" to keep labor employed. The answer given to the rhetorical question above was that there were no markets, that is, demand, for the farmers' products.

What we see here is a forerunner of an essentially Keynesian income-determination model. The Keynesian model is by no means described in full, but what is given is central to what was later the Keynesian innovation, excluding, of course, the major contribution of liquidity preference theory. We can describe a very simple Keynesian model in three equations:

1) $\mathrm{Y}=\mathrm{C}+\mathrm{I}$

2) $\mathrm{C}=\mathrm{f}(\mathrm{Y})$

3) $\mathrm{N}=\phi(\mathrm{Y})$

where: $\quad \mathrm{Y}$ is income

$\mathrm{C}$ is consumption

$I$ is investment

$\mathrm{N}$ is employment

Investment is exogenous, and income, consumption, and employment are determined in the model.

In order to translate the words of the debates into something analogous to this Keynesian model, we need to remember:

1) that we are dealing with a predominantly agricultural economy, where investment and consumption were largely in the hands of the individual farmers, and distinguishing between the two was impossible.

2) that "market" or "consumption" for the Congress meant what "aggregate demand" means to the modern economist, including foreign demand and the government sector; for example, on government demand, "[War] compensates the diminished consumption ... by the people, by the extraordinary consumption of the government." 55

3) that "excess production" was generally the difference between the fixed size of the farm crop and that amount neither sold in the market nor consumed by the farmer himself; it would be called "unintended farm inventory investment" in modern terms; however, there is no reason why it could not include the much less important excess industrial production as well.

Then we can write the model in three equations:

55 Ibid., George McDuffie (S.C.), p. 2406. 
1) $P_{s+c}=C_{p}+C_{g}+C_{f}$ where: $P_{s+c}$ is output either sold or consumed by the producer

2) $C_{p}=f\left(P_{s+c}\right)$

$\mathrm{C}_{\mathrm{p}}$ is private consumption of domestically-produced commodities including business consumption (investment)

3) $\mathrm{N}=\phi\left(\mathrm{P}_{\mathrm{s}+\mathrm{c}}\right)$

$\mathrm{C}_{1}$ is exports

$\mathrm{C}_{\mathrm{g}}$ is government consumption (any government GNP purchases)

$\mathrm{N}$ is employment

Goverment spending and foreign demand ${ }^{56}$ are exogenous, and outpput sold or consumed by the produced, private consumption, and employment are determined in the model. We can add a fourth equation to define excess production:

4) $P_{u}=P_{t}-P_{s+c}$

where: $P_{u}$ is excess production

$P_{t}$ is the total actual production (output)

Now total actual production is exogenous (determined by size of crop planted, etc.) and excess production is determined in the model.

We notice immediately that this model is nearly identical with the simple Keynesian model described earlier.

It is unquestionably exaggerating the case to formulate fragments of various speeches into mathematical or any type of formal model. ${ }^{57}$ But such formulation is really not what is at stake-what is important is that in the minds of the tariff advocates there were these essentially Keynesian notions: the level of employment related to aggregate consumption and equilibrium with involuntary unemployment.

It is not difficult to see how such sophisticated notions were arrived at. The United States had been involved in commercial strife

56 It does not do great injustice to the tariff advocates' position to make exports exogenous, since American trade was seen as a small part of total world trade; however, to satisfactorily account for their view of both exports and imports, one would logically need to introduce the entire monetary sector into the model. Basically, specie flow was seen as the regulator forcing nations to purchase abroad only to the extent that they sold abroad. However, these views were never systematized. See, for example, Ibid., Henry Clay, p. $1962 \mathrm{ff}$. and Salas Wood, p. $2068 \mathrm{ff}$.

57 We must remember that in none of these speeches was there any open attempt to create such a model; in this sense, all of the passages from the debates are taken out of their contexts. But the purpose of this paper is to go behind (or outside of) the context to see what notions the Congress had about the economy. 
or actual warfare from 1807 until 1815. This period was marked by two significant developments: the collapse of foreign trade, particularly imports, and greatly increased government expenditures. Yet these were also remarkably prosperous years, at least in the minds of Congressmen. The return of peace saw large amounts of imports, diminished government expenditures (in fact, repayment of the debt), and great unemployment. Such conditions were correctly perceived by several speakers, ${ }^{58}$ and their observations resulted in the model above.

Other Theoretical Notions. We find little else original in the way of further development of the model. Henry Clay advanced the idea that the demand for money is in proportion to the amount and activity of national wealth (Keynes transactions demand for money?), but he tended to confuse money and income, and thus the value of his insight was vitiated. He did correctly understand the discriminatory effects of deflation and inflation on the debtor and creditor classes. $^{59}$

While the "real goods" definition of national wealth was accepted, the tariff advocates were somewhat more curious about the origin of wealth than their opponents. Their conclusion, if we assume an equivalence between Clay's loosely defined "wealth" and Ricardo's more precise "value," followed strictly Ricardian lines: "Labor is the source of all wealth, but it is not natural labor only; . . . [but also] the power of machinery." "60

Pro-Tariff Implications and Arguments. As one would expect, an analysis based on the Keynesian model outlined above results in typically Keynesian policy implications. Full employment becomes a policy objective, and therefore: "It is the duty of Government to provide employment for all those whom the existing branches of industry will not accommodate, and who are idle for want of employment."61

Perhaps the most persuasive argument for the tariff, then, relates to the aggregate employment benefits to be derived. It was thought

58 Annals, pp. 2406, 2020, 1965.

59 Ibid., p. 1965.

60 Ibid., Henry Clay (Ky.), p. 1973. Compare Clay's statement with the following by Ricardo (Principles of Political Economy and Taxation, London, 1817, Chapter I, Section III): "The exchangeable value of the commodities produced would be in proportion to the labor bestowed on their production; not on their immediate production only, but on all those implements or machines required to give to the particular labor...."

61 Annals, Salas Wood (N.Y.), p. 2017. 
that consumption of domestically-produced articles $\left(C_{p}\right)$ would increase as a result of introducing the tariff; that is, it was expected that the function $f\left(P_{s+c}\right)$ would shift. Furthermore, if this shift could be purchased at minimal export loss, then employment would increase significantly. Nearly every speaker in favor of the bill mentioned employment, and the following is typical: "The object of the protecting duty is to give employment to a multitude of persons who are now idle."62

The tariff supporters argued two further points in favor of the measure:

1) Infant industries: Perhaps derived from Sir James Steuart, who strongly emphasized this argument, but clearly showing the Hamiltonian influence, ${ }^{63}$ the case for protection of infant industries was used nearly as frequently as the employment arguments. It was understood that protection should be temporary and involved short-run costs; however, when combined with the employment argument, the costs were thought to be slight. Currently unemployed American resources would become employed, thereby compensating for the short-run losses which would result from diminished trade..$^{04}$

2) Prevention of dumping: As a result of several "auctions" at which shiploads of British manufactured goods were sold at very slight prices, the tariff advocates urged protection against dumping. It was claimed that British manufacturers would: “. . . throw away cargoes of their goods, at reduced prices, or at no prices, in order to break down a growing rival, and indemnify themselves by fleecing the whole country afterwards."

A Digression on Chapter 23 of The General Theory. J. M. Keynes, in his chapter entitled "Notes on Mercantilism", in The General Theory, notes that there can be two employment-stimulating effects of a favorable balance of trade: the direct effect of increasing aggregate demand through foreign investment, and the indirect effect of reducing the domestic interest rate, which stimulates domestic investment and increases effective demand. He then searches the mercantilist literature to discover whether or not these effects were

62 Ibid., John Wright (Ohio), p. 1502. See also pp. 1964, 1642, 2407.

63 See Hamilton's Report on Manufactures of December 5, 1791 (reprinted in McKee, Samuel Jr., ed., Papers on Public Credit, Commerce, and Finance by Alexander Hamilton; New York: Columbia University Press, 1934); especially pages 203-206.

${ }^{64}$ Annals, pp. 1472, 1553, 1990, 2071, 2263.

65 Ibid., John Tod (Pa.), p. 1473. 
known to those who proposed protective tariffs; he concludes that both effects were recognized, but that "The mercantilists perceived the existence of the problem without being able to push their analysis to the point of solving it."66

Whether or not they can be described as "mercantilists," the tariff advocates of 1824 were not only aware of the employment implications, they in fact devised a theoretical framework that could explain it. Their confusion concerning the role of money prevented them from having any idea of the indirect effect, but their conception of the direct stimulus of import restriction was nearly complete. European markets were shut to American agricultural products, with the exception of cotton and tobacco, and the American market was flooded with foreign manufactured goods. Given this structural arrangement, it appeared that a tariff that would prohibit or greatly reduce the flow of imports must of necessity dramatically-and favorably-change the balance of trade, even after allowing for potential retaliation; if one is buying but not selling abroad, retaliation is irrelevant. These mercantilists expected the employment benefits to be great.

The pro-tariff position, then, was significant in that it refuted the prevailing economic doctrine on intellectual grounds; its proponents refused to be content with commonplace statements that the classical doctrine was fine in theory but did not work out in practice. Instead, they proclaimed that on the employment question the classical doctrine was wrong theoretically-a claim which was not recognized by the economists until a century later.

Quasi-Economic Arguments. There were also a series of quasieconomic arguments used on each side, the principal ones relating to the preservation of national sovereignty through economic independence, the development of a "balanced" economy to foster national unity, the need for federal revenue, and national defense requirements. We need only be concerned here with those arguments that were recognized by the free-trade economists as valid.

Adam Smith admitted four cases for which tariffs could legitimately be established:

$66 \mathrm{~J}$. M. Keynes, The General Theory of Employment, Interest and Money (New York: Harcourt, Brace and Co., 1936) Chapter 23, section IV. J. A. Schumpeter, in History of Economic Analysis, gives a somewhat fuller description of mercantilist thought on the employment problem; he concludes that "some of the mercantilist writers went to surprising, in fact to Keynesian, lengths." (p. 350). The present case seems a good example of that. 
1) to protect defense industries,

2) to offset domestic excise taxes,

3) to retaliate against foreign tariffs before negotiation,

4) to introduce free-trade gradually.

Of these four cases, only the first is frequently discussed in the debates. There existed slight excises on "alcoholic spirits," but since the duty proposed was considerably higher than the excise, the second argument was not used. The third case was mentioned briefly, but it was assumed that Britain's policy was inflexible and therefore this argument was inappropriate. The 1816 debates were concerned with the fourth case, the need for adjustment, but by 1824 de facto free trade had existed for nine years-the duties imposed in 1816 being wholly inadequate to slow the flow of imports.

It would seem that since the free-traders placed such great store in Adam Smith, the tariff advocates would have used his arguments for trade restriction to undercut the free-trade position. From what we know of the Congress's familiarity with The Wealth of Nations, we can be fairly sure that these cases of "legitimate" trade restriction were known. One can only speculate as to the tactics involved which avoided these defenses of the bill.

\section{CASE TWO: THE DEBATES OF 1894}

The years 1824 and 1894 can be seen as polar opposites in the evolution of American tariff policy. In 1824 the commercial condition was one of virtual free-trade, but a majority of the newly-elected Congress was pledged to institute a systematic policy of protection. In 1894, the country had experienced thirty uninterrupted years of increasing protection and high tariffs, culminating in the high McKinley Tariff of 1890. In 1892, however, the Democratic Party had been swept into complete control of the national government on a specific platform of "tariff for revenue only." The Congressional debates in both 1824 and 1894 were exceptional since in both cases the basic issue was protection versus free-trade rather than the more limited question of tariff revision.

A few general comments about the 1894 debates are in order before we turn to the specific arguments advanced by each side. The debate monopolized House business for most of January, 1894, requiring over two thousand pages in the Congressional Record to report it. Regional differences, i.e., the free-trade South and Border States opposing the manufacturing North, made some impact on the 
final vote ${ }^{67}$ but in the end strict party voting prevailed: the Democrats voted in favor of the bill 193 to 15, the People's Party in favor 9 to 1 , and the Republicans against the bill 123 to $0 .{ }^{68}$

Concerning the substance of the debates themselves, we readily detect from reading these debates that a considerable body of economic doctrine existed which was popularly accepted and which therefore belonged to the "public domain." Simplistic notions of supply and demand, division of production into wages and profits, and competition were common to most members of the Congress. However, in contrast to the 1824 debates, the later debates made little explicit use of the writings of professional economists. David Hume, Adam Smith, and J. S. Mill were mentioned, but only perfunctorily. Alfred Marshall, Frank Taussig, and J. B. Clark, all of whom were contemporaries and had published important works prior to 1894 which were relevant to the tariff issue, were apparently not known and their works did not play any major role in the debates. Whatever influence economics authors had must have come through the writings of much more contemporary and policy-oriented authors such as Richard Cobden, ${ }^{69}$ Edward Atkinson, ${ }^{70}$ and Edward Stanwood. ${ }^{71}$ But in general, the debates do not give evidence of the Congressmen having much familiarity with the works of professional economists.

Also in contrast to the situation in 1824 , in 1894 a vast amount of statistics was available from the census. The ubiquitous citations of long series of data reveal more about the Congressmen than about the economy: the speakers had no conceptual means to organize the data, and beyond computing averages, had no techniques to deal with them. Obvious problems were encountered in attempting to decipher the effects of price changes, drawing international comparisons from different bases, and dealing with the distinction between trends and other types of variation. The lack of a theoretical framework, however, was a more serious limitation, rendering meaningless attempts to use empirical evidence. The overwhelming diffi-

67 That, for example, is how the Democratic votes against the bill can be explained.

68 The vote is reported in Record, p. 1994. Congressmen can be identified by party in the Joint Committee on Printing, U.S. Congress, Official Congressional Directory, Fifty-Third Congress, Second Session (Washington, 1894).

69 Record, p. 711.

70 Ibid., p. 802.

71 Ibid., p. 805. 
culty was simply an inability to separate theoretically significant data from the rest. The appeal to "consult the facts" was, of course, irresistible; unfortunately, it was rarely meaningful or decisive.

The 1894 debates only peripherally touched on the aggregate problems of employment, output, and growth. While there was considerable discussion of such concepts as labor and the "nation's industry," was that of micro-analysis, a perspective that looked to the individual firm or entrepreneur for economic laws that could be applied to the entire nation. ${ }^{73}$ The lack of an aggregate perspective can probably be traced to two influences: 1) the nation had enjoyed a relatively long period of prosperity and growth, during which mass unemployment and other macro-problems were perceived as shortlived; 2) the development of professional economics, aside from Marx, tended to focus on micro-analysis, and so at least there was no pressure from this quarter to consider macro aspects.

A more difficult problem was that of separating the effects of tariff changes on the workingman qua wage-earner from the effects on the workingman qua consumer. Clearly the Democrats, and to a lesser extent the Republicans, took as their goal bettering the workingman's standard of living. Yet with few notions of the relevant price, income, and wealth magnitudes involved, differential analysis of the impact of various tariff policies was almost impossible.

Finally, the Fifty-Third Congress found it difficult to separate the effects of thirty years of protection policy from other economic developments during this period. Wages, profits, output, and wealth had grown tremendously in these thirty years. The only free-trade basis for comparison was the pre-Civil War period, clearly not very valuable for judging tariff policy in the 1890's.

With this understanding of some of the background and general problems involved, let us turn to the specific models posited by the two party groups.

\section{Republican Confusion}

When we turn to a systematic study of the protectionist position, we find that the Republicans presented a curious model, seemingly profound but at bottom an almost classic case of economic nonsense. The usual argument made for a protective tariff-an argument gen-

72 Ibid., Charles Bell (Texas), p. 551.

73 Ibid., W. B. Cockran (N.Y.), Appendix, p. 16. 
erally conceded to have theoretical justification-is that the dynamic gains from protection may outweigh the static gains from free trade. But this was not the argument presented, and we can easily see why it was ignored. First, American industry, and certainly those specific industries that claimed protection, could in no way be described in 1894 as "infants;" the case for industrialization through infant industries tariff protection was not viable. Second, what we might call Keynesian employment problems were thought to be random and temporary, a sentiment bolstered by the recent history of presumed high employment and growth. Also, defense was not a major concern. America had not been at war with a foreign power in almost fifty years, and, anyway, defense technology did not at that time require highly specialized industries. The more esoteric argument of bettering the terms of trade was not raised simply because it was not perceived. And finally, the argument that protection was needed to encourage diversity of industry, thereby avoiding the problems of instability due to narrow product specialization, was never made; for obvious reasons, the American economy was already highly diversified.

The Trade Model. What the Republicans did present as their model is a mixture of confused insight and common misconception. At the base of the model is a labor theory of value: "The single and only source of wealth is labor." ${ }^{4}$ All goods produced, including capital, are the products of labor and can be costed at their laborinput values: ". . . capital is nothing more or less than labor in another form or state; it follows that it must have cost in proportion to the price of labor that produced it. . . ."T5 The real cost to society of any production, then, is simply the labor that directly or indirectly went into that production process. The Republicans drew the usual conclusions from this first premise, for example, that labor-saving inventions increase wealth. ${ }^{76}$

When the Republicans turned to the question of trade, the only basis they admitted of was that of absolute cost advantage: "It would be impossible to bring imports from the other side [of the Atlantic] here . . . if it were not for the fact that these articles are produced upon a cheaper scale in the Old World. . . ."77 However,

74 Ibid., John Dalzell ( $\mathrm{Pa}$. ), p. 652. All of the quotations in this section are taken from speeches by Republican Congressmen.

75 Ibid., Myron Wright (Pa.), p. 811.

76 See Ibid., p. 771.

77 Ibid., Charles Daniels (N.Y.), p. 779. 
the Republicans did agree that if the imported goods were produced cheaper abroad than here, then they should be imported: "No protectionist holds that the protective policy should be applied to any industry which must be carried on here under natural disadvantages, that is, where a larger amount of labor is permanently required to make or produce a given article here than is required elsewhere. . ." Th8 That is, national wealth would be increased if the imported goods cost less in labor than the same goods would have cost if they had been produced at home.

Starting from this view of the proper role for trade, the Republicans were led to their justification, indeed theoretical imperative, for tariff intervention by their unique system of calculating labor costs. Real production costs to a society are, they maintained, the direct and indirect labor costs of that production; and it is these costs which form the only legitimate basis for trade, as Dingley's statement above makes clear. It is only when labor costs, in terms of real labor inputs, are lower abroad than here that trade will increase the wealth of the country. These labor inputs are determined by the technological conditions, that is, the state of knowledge and the resource endowment. But trade naturally is carried on in money values, not labor values, and in fact the only ultimate cost component, the price of labor, is set by supply and demand conditions in the labor market: “. . . wages are made [i.e. determined] by supply and demand if all the elements affecting supply and demand are taken into consideration." demand conditions" relate principally to relative scarcity, somewhat to institutional arrangements, but not at all to labor productivity. ${ }^{80}$ The problem, then, is that there may be divergence between money labor costs and real labor costs, with the market catering to money costs but gains-from-trade considerations depending on real labor costs: "The money prices of domestic products are determined by the cost of production, . . . and when they cost more in money than abroad it is simply because labor receives higher wages." ${ }^{11}$ In other words, the natural trade advantage, that is, lower real labor cost, might not coincide with lower money costs. The Republicans argued that in fact for most goods real labor costs were the same or lower ${ }^{82}$

78 Ibid., Nelson Dingley (Maine), p. 731.

79 Ibid., Nelson Dingley (Maine), p. 733.

80 See for example Ibid., pp. 731, 768, 638.

81 Ibid., Nelson Dingley (Maine), p. 730.

82 For any individual good, the American (real) labor cost might be lower, higher, 
in America than abroad, but that money labor costs were higher than abroad. Therefore, in the free market, the United States would import goods that could be made with less real labor input here than abroad but higher money cost, and this importation would conflict with the Republican absolute-advantage theory of how wealth was increased through trade. Protection, then, was needed to cover the disparity between money and actual labor cost comparisons. The market would thus be led to a "correct" solution, in which the proper goods would be traded in the proper amounts in order to maximize the gains from trade.

The essentials of this model can be seen schematically, but with some loss of information, as follows:

let subscripts refer to United States (a) and rest of world (w)

define RC = "real" (labor) costs of production

then:

$$
\mathrm{MC}=\text { "money" costs of production }
$$

(1) $\quad \mathrm{RC}_{\mathrm{a}}=\mathrm{f}\left[(\text { technology })_{\mathrm{a}} ;(\text { resources })_{\mathrm{a}}\right]$

(2) $\quad \mathrm{RC}_{\mathrm{w}}=\mathrm{f}\left[(\text { technology })_{\mathrm{w}} ;(\text { resources })_{\mathrm{w}}\right]$

and:

(3) Real Gains from Trade $=f \quad\left[\mathrm{RC}_{\mathrm{a}} ; \mathrm{RC}_{\mathrm{w}}\right]$ or specifically:

(3a) Real Gains from Trade $=\mathbf{f}\left[\frac{\mathrm{RC}_{\mathrm{w}}}{\mathrm{RC}_{\mathrm{a}}}\right]$ also:

(4) $\left.\quad \mathrm{MC}_{\mathrm{a}}=\mathrm{f}\left[(\text { supply of labor })_{\mathrm{a}} ; \text { (demand for labor }\right)_{\mathrm{a}}\right]$

(5) $\left.\quad \mathrm{MC}_{\mathrm{w}}=\mathrm{f}\left[(\text { supply of labor })_{\mathrm{w}} ; \text { (demand for labor }\right)_{\mathrm{w}}\right]$ and:

(6) $\quad$ Market Trade $=f\left[\left(M_{a} ; \mathrm{MC}_{\mathrm{w}}\right)\right]$ or specifically:

$$
\text { (6a) Market Trade }=\mathbf{f}\left[\frac{\mathrm{MC}_{\mathrm{w}}}{\mathrm{MC}_{\mathrm{a}}}\right]
$$

The Republican theory of the size of the tariff was expressed in the Republican platform of 1892 and quoted by Rep. Dalzell: “. . . that on all importations coming into competition with the products of American labor there should be duties levied equal to the differ-

or the same as labor costs abroad, depending on the relevant technology and resources; and this relationship should determine whether the good gets traded or not. However, taking all goods, general productivity differentials favorable to American labor were explicitly denied; See Ibld., pp. 658, 731, 768, 638. 
ence between wages abroad and at home." ${ }^{\text {83 }}$ Or again, a tariff should be: “. . . a duty which covers the difference of money cost of production and distribution here and abroad of an article which can be produced or made here substantially to the extent of our wants without natural disadvantage."84

Expressing in more generalized and symmetric but mathematically equivalent form, we can write:

$$
\text { tariff }=\left[\frac{\mathrm{RC}_{\mathrm{w}}}{\mathrm{RC}_{\mathrm{a}}}-\frac{\mathrm{MC}_{\mathrm{w}}}{\mathrm{MC}_{\mathrm{a}}}\right] \quad\left[\mathrm{MC}_{\mathrm{a}}\right]
$$

or:

(7a) $\quad\left[\frac{\text { tariff }}{\mathrm{MC}_{\mathrm{a}}}+\frac{\mathrm{MC}_{\mathrm{w}}}{\mathrm{MC}_{\mathrm{a}}}\right]=\left[\frac{\mathrm{RC}_{\mathrm{w}}}{\overline{\mathrm{RC}}_{\mathrm{a}}}\right]$

when this tariff is imposed, equation (6a) changes to:

(8) Market Trade $=f \quad\left[\frac{\mathrm{MC}_{\mathrm{w}}+\text { tariff }}{\mathrm{MC}_{\mathrm{a}}}\right]$

and substituting (7a) into (8):

(9) Market Trade $=f \quad\left[\frac{R_{\mathrm{w}}}{\mathrm{RC}_{\mathrm{a}}}\right]$

thus forcing the market to be dependent on the same variables as equation (3) depends on.

We can see quickly the working of this model from a simple example. Suppose that real labor costs were $\mathrm{RC}_{\mathrm{w}}=3$ and $\mathrm{RC}_{\mathrm{a}}=2$; then, according to Republican theory, we should want this good priced at a 3:2 ratio. However, suppose that $\mathrm{MC}_{\mathrm{w}}=2$ and $\mathrm{MC}_{\mathrm{a}}=4$. This is precisely the case that the Republicans claimed obtained in most markets: the actual cost of the American good was as low or lower than that of the foreign good, but the money price, pushed up by high wages and a high standard of living, was higher. Then a tariff would be imposed (equation 7):

$$
\text { tariff }=\left[\frac{\mathrm{RC}_{\mathrm{w}}}{\overline{\mathrm{RC}_{\mathrm{a}}}}-\frac{\mathrm{MC}_{\mathrm{w}}}{\mathrm{MC}_{\mathrm{a}}}\right]\left[\mathrm{MC}_{\mathrm{a}}\right]=\left[\frac{3}{2}-\frac{2}{4}\right] 4=4
$$

then the goods would compete in the market at the price ratio of $\mathrm{MC}_{\mathrm{w}}+$ tariff : $\mathrm{MC}_{\mathrm{a}}$ or $2+4: 4=6: 4$, precisely the ratio of $\mathrm{RC}_{\mathrm{w}}: \mathrm{RC}_{\mathrm{a}}$.

83 Ibid., John Dalzell (Pa.), p. 651.

84 Ibid., Nelson Dingley (Maine), p. 727. 
It is clear now that the logic of this model (in either its descriptive or schematic form) brings us to an inevitable conclusion: given the institutional environment posited by the Republicans, a tariff was essential for protecting and augmenting American wealth.

Further Points About the Model. The Republicans attempted to document their case by measuring money labor costs according to weekly wages, not as a cost per unit of output:

The proprietor of one of these English shops told me that his pay roll averaged a pound $(\$ 4.86)$ per employee per week. The average [American] pay roll ... was last year $\$ 2$ per day or $\$ 12$ per week; and these two shops are probably fair averages of those on corresponding work in the two countries. I will not dwell on this point, as this difference in wages is not now disputed. $\ldots{ }^{85}$

It must be noted here that if as claimed there were no productivity differentials between countries, and if the work week was of the same length, then weekly wages are indeed an appropriate measure of labor costs. These observations led the Republicans to typical "pauper-labor" conclusions, including a declaration that free-trade is unfair: "Give the American manufacturer foreign wages and he will fear no competition." ${ }^{\text {" A6 }}$ And in the absence of a tariff, American wages would necessarily decline: “. . . But [free trade] . . . involves a reduction of wages to the level of Spanish and Cuban labor. . . ."

As a slight digression from the development of this model, we might pause here to consider one of the implications of what has already been said. If we accept the claim that there were no productivity differentials between European and American labor, then the higher American wages must have resulted from one of two situations:

1) American labor was paid more than its marginal product; that is, capital was receiving less than its marginal product. However, the Republicans were clearly not sacrificing the returns to producers in order to achieve higher real wages for labor:

There is no difference of interest between classes on this question. [The tariff] is either better or worse for all classes; . . . it is a necessity of the case, if [factories] do run, that there shall be a profit in running them, equal at least to the average profit of other business in the country. ${ }^{88}$

85 Ibid., William Draper (Mass.), p. 802.

86 Ibid., William Draper (Mass.), p. 805.

87 Ibid., Julius Burrows (Mich.), p. 577.

88 Ibid., William Draper (Mass.), p. 802. 
2) Alternatively, foreign labor was paid less than its marginal product, and foreign capital more than its marginal product. But the Republicans likewise rejected this situation, by accepting the notion that foreign producers also received less than their marginal product: "Free trade discourages production among our own people because the foreign producer can live cheaper, and work cheaper, and sell cheaper. . . ." 89 Why both foreign labor and capital should be so perverse as permanently to accept lower returns than their marginal products is, of course, never explained.

The protectionists' insistence on absolute advantage as the only basis for trade led them to a narrow view of the adjustments that would follow the opening of freer trade. In the first instance, they were unable or refused to see that while some industries would necessarily decline, others might grow: "One industry after another would be destroyed by this low-priced labor abroad, and pauperism would be increased in America." were not enough industries with an absolute advantage over foreign competitors to keep the labor force employed: "We have no advantageous industries which can employ all our labor in the production of commodities whose excess over and above our own consumption can find a market elsewhere. . . ."91

The Republican model is easily recognized as a somewhat refined combination of the "pauper labor" and "scientific tariff" arguments. ${ }^{92}$ Its basic fallacy, of course, lies in its confusion between real costs and values and money costs and values. ${ }^{93}$ It is clear from the model that one cannot consistently maintain that both real wages and real profits are higher in the U.S. than abroad and also maintain that there are not productivity differentials as well; one cannot cut the same pie into larger pieces for everyone. But this inconsistency emerges only from the model, and in fact is seen only by lifting the model from its massive rhetorical context.

From the limited scope of this study's data, it is not possible to tell how much of the model was believed and how much was dictated by political necessity; but if we choose to trust their sincerity,

89 Ibid., Binger Hermann (lowa), Appendix, p. 508.

90 Ibid., Albert Hopkins ( $\mathrm{Pa}$. ), p. 638.

91 Ibid., Marriott Brosius (Pa.), p. 746. See also p. 607.

92 P. T. Ellsworth, The International Economy, 3rd Edition. (New York: The Macmillan Company), 1964, pp. 227-230.

93 This is a confusion that the Congress of 1824 avoided by refusing to discuss money variables; it documents the argument made above that consideration only of real values was a tremendous and important simplification for that Congress. 
the Republicans in Congress demonstrated little understanding of the economic process.

\section{Democratic Innocence}

The Basic Tariff-Reform Model. When we turn to the Democratic position, we find that the tariff-reformers were as ambitious in their schema and as naïve in their observations as the Republicans. The Democratic majority in Congress took as its principal tariff-reform goal the raising of real wages paid to labor. The tariff bill of 1894 proposed to achieve this rise in real wages by focusing "reform" in two areas: first, it put raw wool, iron ore, coal, and lumber, all raw materials, on the duty-free list; second, it reduced the duty on such items as refined sugar and steel, which were produced domestically under trusts or combines.

Precisely how cheaper raw materials would get translated into higher real returns to labor is explained by the tariff-reform model. In the opening speech of the debate, William Wilson laid out the basic position:

[The workingman's] wages depend on the products of his labor. Whatever goes as a tax into the material he uses is a diminution of the wages of the laboring man. As you cheapen his materials, ... you enable him to put his finished products on the market at prices that will rapidly and indefinitely increase [his wages]. ${ }^{94}$

The fundamental proposition for the model that emerges from Wilson's statement is the two-fold relationship of wages: wages vary directly with the value of output and inversely with the price of other variable inputs.

The second feature of the model is most clearly explained a little later in the debate:

If . . the supply should exceed the demand [for any good], competition amongst the owners of the commodity would cause the price to decline until they could only obtain the cost of their possessions and a reasonable compensation for the use of their capital invested and for their personal services. ${ }^{95}$

The proposal stated here is simply that in a competitive system excess profits should be zero: the return to capital is "a reasonable

94 Record, William Wilson (W. Va.), Appendix, p. 196. All of the quotations in this section are taken from speeches by Democratic Congressmen.

95 Ibid., Charles Bell (Texas), p. 550. 
compensation," in addition to which the entrepreneur receives payment for his managerial services.

The third condition, needed to make this model viable, is that real inputs are somehow directly related to real output, in some sense a production function; phrasing the connection rhetorically, W. B. Cockran asks: "Is it axiomatic in political economy that the capacity of an individual to employ labor bears a fixed relation to the amount of capital at his disposal? And is the same rule applicable to nations that applies to individuals?"96 Later he answers his own question: "[When you diminish] production you diminish the amount of labor and the quantity of materials employed in production."97

The fourth point is also contained in the portion of Cockran's speech quoted above: the model is essentially a micro-economic picture of a firm generalized to the entire economy. The "generalization" process is a simple carry-over, in which conclusions about parts are expected to hold for the whole; the methodology proceeds on the assumption that the "rule applicable to nations" is derived from observing individuals.

We are now in a position to gather the above elements into a model, along with certain simple definitions, and view the system critically. Profits, including return to capital, are simply the difference between total revenue and total operating costs:

$$
\begin{aligned}
\text { (1) } \pi=\mathrm{TR}-\text { TOC } \quad \text { where: } & \pi \\
& \text { TR }=\text { profits } \\
& \text { TOC }=\text { total revenue } \\
&
\end{aligned}
$$

Total revenue is output price times quantity:
(2) $\mathrm{TR}=\mathrm{P}_{\mathrm{o}} \bullet \mathrm{Q}$
$\mathrm{P}_{\mathrm{o}} \quad$ = output price
$\mathbf{Q}=$ output quantity

Total operating cost is composed of labor cost plus the cost of raw materials:

(3) $\mathrm{TOC}=w \mathrm{~L}+\mathrm{P}_{\mathrm{m}} \mathrm{M}$

$$
\begin{aligned}
& \mathrm{w} \text { = wage rate } \\
& \mathrm{L} \text { = labor } \\
& \mathrm{P}_{\mathbf{m}} \text { = price of raw materials } \\
& \mathbf{M} \text { = raw materials }
\end{aligned}
$$

These simple definitions were part of the "public domain" of economic knowledge and are thoroughly documented in the debates. Substituting (3) and (2) into (1) gives us:

(4) $\pi=\mathrm{P}_{\mathrm{o}} \mathrm{Q}-\mathrm{wL}-\mathrm{P}_{\mathrm{m}} \mathrm{M}$

96 Ibid., W. B. Cockran (N.Y.), Appendix, p. 16.

97 Ibid., W. B. Cockran (N.Y.), Appendix, p. 17. 
Equation (4) is an exceedingly short summary of the basic model, but given two assumptions it reflects the tariff-reform thinking remarkably well. The first assumption is that under conditions of competition profits are constant; that is, we assume $\pi$ is fixed at the level of "reasonable compensation." Secondly, based on their recent experience of having the labor force nearly at full employment for a considerable period, the Democrats assumed that the effective labor force could not be expanded much in the short-run; that is, the labor supply was believed highly inelastic above the contemporary employment level.

Let us now examine the effects of the tariff bill in terms of equation (4). The first part of the bill reduced the tariff on, and therefore the prices, $\mathrm{P}_{\mathrm{m}}$, of raw materials. If $\mathrm{P}_{\mathrm{m}}$ declined and $\pi$ remained constant (by the competition assumption), then qualitatively there are five possible adjustments simply to balance the equation:

1) $M$ could increase;

2) L could increase;

3) w could increase;

4) Q could decrease;

5) $P_{0}$ could decrease.

We remember that $Q, L$, and $M$ are related in fixed proportions. Thus if adjustments (1) or (2) occur, both must occur and $Q$ must necessarily increase also. But $\mathrm{L}$ is assumed fixed upwards at full employment, and thus ( 1 ) and (2) cannot occur. ${ }^{99}$

The possibility of adjustment (4) is likewise excluded, since competition would not permit reduced production in the face of reduced input prices. $\mathrm{M}$ and $\mathrm{L}$ would also have to decrease, by the fixed proportions argument, further reducing input prices.

Finally, w could increase (adjustment 3 ) or $\mathrm{P}_{\mathrm{o}}$ could decrease (adjustment 5); either one of these or some combination of both would be possible, each being a single adjustment having no wider repercussions in the equation and each capable of exactly offsetting the decline in prices of raw materials. These adjustments were precisely those which the tariff-reformers expected, because each also

98 This dubious assumption is investigated more fully below.

99 Certainly if there were unemployed labor resources, adjustment (2) would be beneficial; in fact, it was recognized as a possibility: "If production be unrestricted by law we believe trade [i.e., production] will increase so that the demand for labor in this country will exceed the supply ... and the result of the competition will be to raise his wages and improve his condition. ..." Record, W. B. Cockran (N.Y.), Appendix, p. 18. 
would raise the real wages of labor. The following statement, expressed in negative form, accurately reflects the expectation of (3) and (5):

Under [the tariff system], which increases the cost of the goods, or rather the selling value of the goods made by the protected manufacturer, you diminish the purchasing power of the wages of the laborer while ... you have already reduced the compensation he receives for his labor. ${ }^{100}$

The second part of the tariff bill aimed to reduce the duties on those goods produced domestically under trust or combine arrangement. Again with reference to equation (4): “. . protection enables manufacturers to obtain better prices for their products. . . ."101 By restricting competition, the trusts were able to raise profits above the "reasonable compensation" level; that is, the increase in $\mathrm{P}_{\mathrm{o}}$ due to the tariff was met by a rise in $\pi$ : "Active foreign competition being shut out by a high protective tariff. ... [the trusts] kill competition, arrange prices to suit themselves, and regulate production according to demands at their high extortionate price."102 Thus in practical terms the workingman was simply faced with higher prices, hence lower real wages. So by reducing duties on these consumer goods, real wages were likewise raised.

Equation (4) and its accompanying behavioral assumptions represent the brief essentials of the Democratic vision of the economic system. At the least it was a plausible attempt rationally to reconcile the goals of tariff reform with the specific tariff reform chosen.

Shortcomings in the Model. To the modern economist-indeed, to the economist of 1894 - the model depicted in equation (4) appears extremely naïve. The arguments based on it represent a good example of theoretically valid policy conclusions resulting from underlying theoretical confusion. There is first the failure to take account of Keynesian problems: the levels of national output, employment, and prices are really not considered in the aggregate. However, more serious shortcomings arise in attempting, as the reformers did, to use the model as an accurate micro-analytic description. There are at least five theoretical problems that arouse suspicion as to the validity of the model, even in its limited micro application:

1) The most obvious is that there is no reason for profit levels to

100 Ibid., Michael Harter (N.Y.), p. 740.

101 Ibid., Charles Bell (Texas), p. 550.

102 Ibid., William Breckinridge (Ky.), p. 716. 
remain constant as opposed to profit rates being equal. Competition will insure that "excess" profits are zero in equilibrium, but this only insures that rates of profits between industries be equal, not that overall profits somehow remain fixed. Once we release $\pi$ to vary, then, there is no assurance that declining materials prices will get translated into higher real wages. Even in a completely static economy, changing relative prices will not in general leave aggregate profits constant. In fact, it was known that the capital stock was growing: "Capital increases from year to year in any country by the amount of its product that is saved from consumption."103 The question becomes much more complicated when there is positive net investment and total income is rising. However, so long as the reduction in tariffs does not call forth such a large increase in profits as actually to reduce real wages, then the constant profits assumption can be relaxed without serious damage to the model.

2) The model completely disregards capital. Certainly various tariff policies would have differential effects on the application of and returns to capital, yet these problems are never explored. The notion of constant variable-input-output relations (i.e., fixed coefficients between variable inputs and output) does not appear to be a significant limitation, since the possibility of substituting capital for labor was recognized. However, leaving capital out of consideration restricts the applicability of such concepts as substitution of inputs.

3) "Raw materials" is a difficult concept to define in terms of a modern industrial economy. The Republicans forcefully pointed out that materials inputs to one firm are simply outputs to another-and this problem becomes increasingly complex as the number of production stages between initial producer and ultimate consumer increases, as obtains with industrial progress. The total effect, then, on real wages is no longer unambiguous: for example, if the price of raw wool declines, and assuming that this decline gets translated into a decline in the price of woolen goods, then the real wages of woolens consumers go up but those of workers in the production of raw wool may go down. Without some concept of magnitudes, it is not clear what has happened to real returns to labor.

4) The tariff reform model leaves out of consideration the critical problem of whether labor was a relatively scarce or abundant factor.

108 Ibid., W. B. Cockran (N.Y.), Appendix, p. 16. 
The effects of tariff changes on relative income shares cannot be determined in ignorance of the relative scarcity.

5) Comment (4) refers to division of a fixed income, but there is also the problem of effects on growth of income, which the model likewise ignores.

The Sophisticated Free-Trade Position. In addition to the naïve tariff-reform model presented above, the more militant free-traders posited relatively more sophisticated notions; in fact, their version approximated the economist's classical comparative-cost trade model. Charles Bell put forth the essential postulate of this theory:

... in fact the more they [people] trade the richer they get if each receives from the other something he needs which it would have taken him longer to produce than it did to produce the article he parted with for it. When people are not hampered by restrictive legislation, . . . experience soon demonstrates where the various necessities or luxuries of life can be produced with the least expenditure of labor, and they adapt themselves to the conditions prescribed by the laws of nature. ${ }^{104}$

The importance of the above statement is that Bell compares the real cost of a desired imported article to the real cost of the exported good for which it is traded, rather than to the cost of the desired article if produced at home. The latter comparison is, of course, the absolute-advantage case, which was recognized as well; as usual, it evoked the typical plagiarism of Smith's "hothouses in Scotland" argument. ${ }^{105}$ But Bell makes the much stronger statement of comparative advantage, exposing consumption possibilities based on a trading line. This was a significant advance over the Republicans' previous recognition of only the absolute-advantage case, which, as we saw, led them to fear "pauper" labor.

To complete our survey of the free-trade assumptions, we need to introduce three further strands of thought:

1) There was a clear understanding of the difference between weekly wages paid to labor and labor cost per unit of output: "It is undoubtedly a fact that laborers of all kinds received better compensation in this country than elsewhere, if we estimate it in money by the week; but if we estimate their compensation by the results accomplished, then such is not the case."106 Or again, "... invention renders labor so efficient that we can maintain the rate of wages, that

104 Ibid., Charles Bell (Texas), p. 555.

105 Ibid., p. 555.

106 Ibid., Charles Bell (Texas), p. 550. 
we can shorten the hours of toil and still cheapen production."107 This distinction, so obvious to economists as to be hardly worth noting, is crucial to any clear view of the relevant economic processes; yet this distinction was not admitted by the Republicans.

Further, it was seen that high real wages were possible because of the high productivity of the American worker: "The higher the skill, the higher the intelligence; the higher the capacity, necessarily the higher the wage. . . ."108

2) The Democrats understood the static argument that lower real domestic production resulted from tariff restriction, and that this decline in production occurred precisely because the tariff acted as a subsidy to inefficient industries. Both inefficient firms in an otherwise efficient industry and entirely inefficient industries, in terms of international comparisons, would be subsidized by a tariff: "[the tariff] encourages men to engage in trades that they cannot carry on in equal competition. . . ."109 Finally, the cost of supporting inefficient industries was seen as precisely those goods which were foregone in the production of goods which were produced. ${ }^{110}$

3) There was an implicit recognition of the terms-of-trade problem, although the influence of a tariff on the terms of trade was skillfully avoided. But in the case of expert bounties granted by the German and Austrian governments to their sugar exporters, and against vehement Republican claims of unfair competition, the freetraders argued that ". . . . if Germany is fool enough to spend money to give our people cheap sugar, . . . let her do it. . . ."111

SOME CONCLUSIONS ABOUT CONGRESSIONAL KNOWLEDGE AND THE NATURE OF CONGRESSIONAL DEBATE

In concluding, we must note first the inescapable impression that both sides in the 1824 debates showed themselves extremely knowledgeable - they knew what the political economists were saying and they were clever in making original observations about the economy. While generally confused about money and prices, the Congressmen were nevertheless clear on the problems of resource allocation, income and employment levels, the gains from trade, and growth.

The Congress of 1824 refused to accept as applicable to a national

107 Ibid., W. B. Cockran (N.Y.), Appendix, p. 14.

108 Ibid., William Breckinridge (Ky.), p. 711 .

109 Ibid., W. B. Cockran (N.Y.), Appendix, p. 16. See also pp. 740, 659.

110 Ibid., p. 740 .

111 Ibid., John Warner (N.Y.), p. 660. 
economy those common-sensical postulates on which a good business is managed. In some cases they came up with wrong notions, but they did produce important insights relevant to an economic system. Less concretely, there was in the 1824 debates a tone of honest inquiry directed at discovering economic knowledge; their inquiry met with notable success.

It is generally claimed that the tariff advocates had a large majority of votes when the 1824 debates began, but that during discussion of the bill they were "outgeneraled" by the free-traders and lost much of their majority. ${ }^{112}$ While the problem of what motivated men to vote as they did is beyond the scope of this paper, we can observe possible intellectual reasons for this claim: the free-traders inherited their model in complete form from the political economists and were able to employ its arguments from the opening day of the debate; on the other side, the tariff advocates began with no model and only slowly developed one in the course of the debate. Given this vast difference in original endowments, perhaps the most remarkable aspect of these debates is that the tariff advocates were eventually able to present such a cogent defense of the bill on theoretical grounds.

It is readily apparent that comparison of the debates of 1824 and 1894 reveals a regression of Congressional understanding of the economy. Despite having available a more complete set of data and a fuller theoretical description of the economy by professional economists, the later Congress demonstrated an inability to develop an economic perspective commensurate with the analytic task at hand.

The Congress of 1894 displayed none of the intellectual curiosity of their predecessors. The policy positions were strictly defined before the debate and never weakened. The intellectual justification for either program was not carefully prepared or subjected to tests of consistency. There was little discussion of long-range effects beyond emotional or irrational predictions of economic disaster or increasing bliss.

This description of the economic sophistication of the American Congress at the beginning and end of the nineteenth century supports the hypothesis that the nature of Congressional debate itself changed during this period. Despite the geographical consistency of

112 For this view, see Edward Stanwood, American Tariff Controversies in the Nineteenth Century (Cambridge, Mass.: Harvard University Press, 1903), pp. 204207. 
the actual voting, the content of the debates makes clear that the earlier Congress convened for honest debate and discovery of knowledge through mutual interchange of ideas. The later Congress debated the issue only as a formality to be endured before the final and entirely predictable vote. The explanation of the difference between the two periods might well be sought in the respective contexts of interests and values in which the debates were staged.

Richard C. Edwards, Harvard University 